\author{
FruZsina Gárdos-Orosz, Krisztina Nagy
}

\title{
The Development of the Hate Speech Regulation in Hungary: from Criminal Law to Civil Law and Media Regulation
}

\section{Introduction}

The term 'hate speech' collectively refers to expressions which are directed against the foundations of the democratic political system, primarily by citing elements of totalitarian ideologies. More specifically, these are expressions which propagate racial, ethnic or nationality-national superiority and incite hatred on such grounds. The characteristic of hate speech is that the conduct is directed against a community, and the statement defames the common trait of the members of that community, which forms the basis of their membership and an essential feature of an individual's personality (e.g. religious belief, national-ethnic origin). In other words, this form of expression comprises statements through which the speaker, usually driven by prejudice or hatred, expresses some opinion about racial, ethnic, religious, gender groups of society or certain members of such groups, which may harm the members of the group and may incite hatred in the society towards that group. ${ }^{1}$

In Hungary under existing law, one of the conducts motivated by racism or xenophobia, and incitement against a community, is penalised by criminal law. In addition to that, current administrative law, civil law and media law also contain relevant provisions. ${ }^{2}$ This paper provides an overview of these provisions and evaluates the complex system that has been created in Hungarian law since the democratic transition of 1989-1990, in order to penalise conducts inciting hatred. ${ }^{3}$

1 A. Sajó, A szólásszabadság kézikönyve, Budapest 2005, p. 68.

2 The most current summary about the Hungarian hate speech regulation: A. Koltay, The Clear and Present Danger Doctrine in Hungarian Hate Speech Laws and the Jurisprudence of the European Court of Human Rights, in: Comparative Perspectives on Freedom of Expression, ed. A. Koltay, R. Weaver, M. D. Cole, S. Edland, „The Global Papers Series”, 2017, vol. II, Durham, pp. 3-44.

3 Selected parts of the paper are based on: F. Gárdos-Orosz, The Regulation of Offensive Speech in the New Hungarian Civil Code, „ELTE Law Journal” 2015, no. 3, pp. 103-123. 
The framework defined for criminal law, also in international law, cannot be applied from a number of aspects to assess the possibilities of civil law and media-administrative law, because the subject-matter of the protection is different for the three fields of law. ${ }^{4}$ The subject-matter protected by criminal law is public peace, first and foremost. However, in addition to the need of establishing that the public peace has been breached, the statutory definitions of crimes, to various degrees, require that absolute/subjective rights need to be directly or indirectly violated or threatened. The statutory definition of incitement against a community, however, does not require that a criminal act must be the result. In civil law regulations, the protected legal interest is different from that of criminal law: Civil law protects personality rights as absolute/subjective rights. International regulation may also reflect that no European hate speech regulatory regime has attempted to use civil law specifically and recently to sanction hate speech in general. Examples from foreign countries show instead that in most countries hate speech is only sanctioned by criminal law. In some states, relevant statutory provisions also appear in anti-discrimination law, media law or a separate anti-hate speech law and, in Englishspeaking countries, so-called 'public order acts' penalise certain forms of conduct. ${ }^{5}$ There are, however, some unique (but not representative) exceptions that have historical roots.

For instance, the French Press Law of 1881 regulates hate speech but uses methods of criminal law (i.e. it gave the definitions of various crimes, including a definition of hate speech). However, Section 48-6 allows members of a community to make a claim (e.g. for damages) in a hate speech criminal procedure as if its members' rights had been violated directly. ${ }^{6}$ This rule may be regarded as a step towards civil law (damages), but it is not an ideal answer to the original question of how hate speech may be regulated within the framework of personality rights and in administrative law and media regulation.

According to Michel Rosenfeld, in Germany it is very easy to reach the level of a criminal law violation, which is why the kind of regulation the state will develop using civil law methods is not a pressing issue. ${ }^{7}$

In English law, the 'hatred, contempt or ridicule' and the 'to cause to be shunned or avoided' formulas have been part of case-law since 1724 and 1679, respectively, in connection with defamation tort. ${ }^{8}$ Today, torts are considered neither private law nor public

4 Constitutional Court Decision (ABH) 1992,167,172; G. Halmai, A. Tóth, Emberi jogok, Budapest 2003, p. 436.

5 P. B. Coleman, Censored: how European 'hate speech' laws are threatening freedom of speech, Vienna 2012, pp. 98-134.

6 Law on the Freedom of the Press of 29 July 1881. The relevant rule was modified in 1996.

7 M. Rosenfeld, Hate Speech and constitutional jurisprudence, a comparative analysis, in: The Content and Context of Hate Speech. Rethinking Regulation and Responses, ed. M. Herz, P. Molnár, Cambridge 2012, p. 268.

8 L. Sólyom, A személyiségi jogok elmélete, Budapest 1983, p. 186. 
law concepts, as they contain private law, administrative law and criminal law elements. ${ }^{9}$ It is very difficult under English tort law, but by no means impossible, to claim that offending a community resulted in a tort. If a group is relatively small and easily definable and thus the individual is able to prove that the offensive conduct affected each member of the group in person, or if the individual can give evidence that the statement concerning the group actually extended to the individual, a tort can be established under English judicial practice. In the Knuppfer v. London Express Nerwspapers Ltd. case, the court explained that, if a community is offended, it is up to the court to decide if the violation of rights should be applied to a member of the group. ${ }^{10}$ Today, however, hate speech in the UK is primarily penalised by public order acts, which are of an administrative character.

However, the facts that there is no concrete standard in international law for the detailed regulation of hate speech and that the European models are not similar one to the other, does mean that the standards and methods based on the proportionality of the legal measures generally would not be accepted. ${ }^{11}$ The Hungarian model has tried to implement the proportionality of the legal action against offensive speech by implementing a threefold solution that incorporates criminal law, civil law and administrative law/ media regulation measures.

\section{The Traditional Criminal Law Measures and Their Limits}

When interpreting Article 61 of the former Hungarian Constitution, the freedom of expression, in its Decision no. 30/1992. (V. 26.) AB, the Constitutional Court adopted both the justification of free speech on grounds of individual freedom and autonomy and the so-called instrumental justification that focuses on serving democratic values. ${ }^{12}$ This means that the freedom of expression is a protected value, because being able to freely express their opinion on the realities of the world is essential for people to develop their personality freely (autonomy); but the freedom of expression is also protected on grounds that opinions contribute to the exposure of good ideas, and the expression of opinion is an indispensable condition (instrument) for the functioning of democracy. In its Decision no. 30/1992. (V. 26.) AB, the Constitutional Court found that even offensive expression enjoys the protection of freedom of speech, therefore it can be limited only if the expression perceptibly infringes individual rights and the limitation is

9 Ibidem, p. 193.

10 P., Giliker, S. Beckwith, Tort, London 2000, pp. 293-294.

$11 \mathrm{~J}$. Gerards, How to improve the necessity test of the European Court of Human Rights, "International Journal of Constitutional Law" 2013, vol.11, p. 466.

12 G. Halmai, Criminal law as means against hate speech? The Hungarian Legal Approach, „Journal of Constitutional Law in Eastern and Cetnral Europe"1997, vol. 4/1, pp. 41-42. 
necessary and proportionate to the intended purpose. This means that the freedom of expression has no internal limitations, differentiation on the basis of content is unconstitutional. However, it has external limitations to safeguard the constitutional rights of others. ${ }^{13}$

The Constitutional Court examined the prohibition under criminal law (Section 269 of the Criminal Code) of the most dangerous forms of hate speech.

The constitutional framework of criminal law means against hate speech is defined not only by the provisions of the Constitution, but also by the content of the Constitutional Court decisions referred to above, and by the general requirements formulated by the Constitutional Court. In its Decision no.32/1992. (V. 26.) AB, the Constitutional Court did not find it unconstitutional that those who incite hatred are threatened by criminal sanction.

Providing constitutional protection to inciting hatred against specific groups of people within the scope of free speech and free press would indissolubly contradict the political model and values expressed in the Constitution, as well as the constitutional principles of the democratic rule of law, the equality and equal dignity of people, the prohibition of discrimination, the freedom of conscience and religion, and the protection and recognition of national and ethnic minorities.

Later, however, the Constitutional Court declared all other legislative efforts intended to sanction hate speech under criminal law unconstitutional. For example, defamation and humiliation of others, or claiming that an individual or a group of individuals is inferior or superior on grounds of nationality, ethnic origin, race or religion cannot be sanctioned; neither can the offensive or degrading speech before a wide public against communities identified by law or any other acts capable of inciting hatred against communities; nor inciting hatred against communities or even provocation of violence, if the action does not reach the threshold where the means of criminal law become applicable.

In its Decision no. 18/2004. (V. 25.) AB, the Constitutional Court narrowed down the scope of punishable acts constituting incitement against a community, and as a result, the applicability of this provision has become very limited. Some statements of the decision made it clear that the issue of hate speech should not necessarily be treated by means of criminal law. As the Constitutional Court stated in its decision on the constitutionality of the statutory definition of scaremongering:

Criminal law is the ultima ratio in the regime of legal liability, and the criminal sanction should only be applied to maintain the legal and moral standards when the sanctions imposed under the other branches of law are inadequate. By criminalising defamation, the legislator did not choose the least restrictive means to the freedom

13 P. Molnár, Towards improved policy and hate speech - the clear and present danger doctrine in Hungary, in: Extreme speech and democracy, ed. I. Hare, J. Weinstein, Oxford 2009, pp. 237-243. 
of expression to safeguard the right to human dignity. Since there are other protective measures that sanction the conducts described in the crime of defamation, which limit the freedom of speech to a lesser extent yet effectively, in case of defamation or humiliation the Constitutional Court considered the threat of a criminal sanction to be a disproportionate restriction to the freedom of expression enshrined in Article 61(1) of the Constitution.

Accordingly, the consistent view of the Constitutional Court is that the constitutional problem of hate speech cannot be treated by broadening or extending the scope of criminal law protection.

In its Decision no. 95/2008 (VII. 3.), the Constitutional Court, at the request of the President of the Republic, also reviewed the amendment that inserted blasphemy into the Criminal Code. According to the Decision, the Constitution guarantees the right to the expression of opinion equally to all, and this constitutional protection cannot be denied for the sole reason that the expressed opinion harms the interests, views or sensitivity of others, or because they are degrading or offensive for certain individuals.

The Constitutional Court, therefore, declared the crime of blasphemy newly adopted by the Parliament as unconstitutional. It stated that the use and spreading of abusive terms or the use of gestures like that itself does not pose a direct and obvious danger of violence and does not violate any individual's rights. Although the Criminal Code amendment uses the terms honour and human dignity, there is no constitutional right opposed to the freedom of expression that could be protected by the new crime.

\section{The New Constitutional Framework for the Further Regulation of Hate Speech}

The Fourth Amendment to the Fundamental Law in 2013 supplemented Article IX on the freedom of expression in an attempt to lay the constitutional foundations of a number of items in Section 2:54 of the Civil Code. ${ }^{14}$ The Amendment, however, did not affect

14 Following the Fourth Amendment, the following provisions comprise the constitutional environment of Section 2:54 of the Civil Code: 'Human dignity is inviolable. Everyone shall have the right to life and human dignity; the life of the foetus shall be protected from the moment of conception.' (Article II of the Fundamental Law) 'The inviolable and inalienable fundamental rights of MAN shall be respected. It is the primary obligation of the State to protect these rights. Hungary recognises the fundamental individual and collective rights of man. The rules for fundamental rights and obligations shall be laid down in an Act. A fundamental right may only be restricted to allow the application of another fundamental right or to protect a constitutional value, to the extent absolutely necessary, proportionate to the objective pursued and with full respect for the essential content of that fundamental right. Fundamental rights and obligations which by their nature apply not only to Man shall be guaranteed also for legal entities established by an 
Article II of the Fundamental Law on the right to human dignity, which declares that the subjects of this right are human beings, or Article I on the possibility of restricting fundamental rights, which states that rights (including the right to human dignity and the freedom of expression) may be restricted if the requirements of proportionality and necessity are met. ${ }^{15}$

However, the new paragraph (5) of Article IX of the Fundamental Law states that ' $[t]$ he right to freedom of speech may not be exercised with the aim of violating the human dignity of others.' Also, according to the Fundamental Law, the right to freedom of speech may not be exercised with the aim of violating the dignity of the Hungarian nation or of any national, ethnic or religious community.

According to the relevant reasoning of the Fourth Amendment to the Fundamental Law, the proposed text's objective is to declare, at the level of the Fundamental Law, that human dignity may restrict the freedom of expression, and to lay the constitutional foundations for the possibility of penalising certain forms of hateful expressions by civil law means if the dignity of communities is violated. As it was not possible to combat hate speech effectively at the level of Acts of Parliament, it is justified to amend the Fundamental Law to this end. The proposed amendment's objective was to provide protection against communication violating the dignity of the listed communities. ${ }^{16}$

The Amicus Brieffor the Venice Commission on the Fourth Amendment to the Fundamental Law of Hungary ${ }^{17}$ edited by Gábor Halmai and Kim Lane Scheppele, includes a separate chapter evaluating this rule of the Fundamental Law. I concur with the following statements of the chapter: according to this opinion, one interpretation of the new rule of the Fundamental Law is that the amendment forms an exception, a lex specialis applicable to the assessment of restrictions on the freedom of expression and overriding the general limitation clause of Article I (3) of the Fundamental Law. However, the Amicus Brief claims that this would clearly run counter to practice recognised by international law.

Act.' (Article I of the Fundamental Law) 'Everyone shall have the right to freedom of speech. The right to freedom of speech may not be exercised with the aim of violating the human dignity of others. The right to freedom of speech may not be exercised with the aim of violating the dignity of the Hungarian nation or of any national, ethnic, racial or religious community. Members of such communities shall be entitled to enforce their claims, as provided for by an Act of Parliament, in court against the expression of an opinion which violates the community, invoking the violation of their human dignity.' (Article IX of the Fundamental Law) Another relevant provision is Section 5 of the Fundamental Law's closing and miscellaneous provisions, which declares that Constitutional Court rulings given prior to the entry into force of the Fundamental Law will no longer be effective. This provision is without prejudice to the legal effect of those rulings.

15 The concept of inviolability, which was part of the Constitution in effect until 2012, never meant that what it referred to could not be restricted. F. Gárdos-Orosz, Alkotmányos polgári jog? Az alapvetó jogok alkalmazása a magánjogi jogvitákban, Budapest 2011, pp. 403-404.

16 http://www.parlament.hu/irom39/09929/09929.pdf [access: 14.11.2015].

17 Amicus Brief for the Venice Commission on the Fourth Amendment to the Fundamental Law of Hungary by Orsolya Salát in: "Fundamentum" 2013, vol. 3. 
According to the author's opinion this is because the Fundamental Law permitted the necessary restriction earlier and, therefore, the only possible reason behind the amendment is to introduce a different standard, a lower protection to the freedom of expression than required based on the necessity and proportionality tests.

The Amicus Brief examines European examples and trends to conclude that the restriction of the freedom of expression to such extent in the interest of the Hungarian nation as a community is not acceptable in a democratic society, not even if the restriction is made through civil law means. ${ }^{18}$

To resolve the contradictions of the Fundamental Law, Imre Vörös recommended a solution that conforms to the theoretical/logical foundations of law and allows, through a loophole, a constitutional interpretation that meets European requirements to be reached. ${ }^{19}$ In his opinion, a fundamental right is by definition a right with a special status and its essential content may not be restricted at all. The constitution, by incorporating a limitation standard specifying the framework of restricting fundamental rights by law, actually codifies the 'absolute, unrestricted standard' and all laws passed in connection with the fundamental right must be assessed on the basis of this standard. The special standard may not violate the general standard specified in the Fundamental Law, in contrast with the principle of civil law regulation, which is built on private autonomy. It is safe to conclude therefore that, for example, a rule affecting human dignity may not restrict the right to human dignity itself. If the content of the fundamental right understood to be part of the original standard is restricted in the Fundamental Law itself, there will be two contradictory standards in the Fundamental Law, and therefore the fundamental right will not be able to play its 'benchmark' role for legislation. According to Imre Vörös's paper, in such cases it is unclear whether the fundamental right should be understood with the content established with regard to the restriction standard of the Fundamental Law or with the content restricted by other provisions of the Fundamental Law, which makes the content of the fundamental right uncertain. ${ }^{20}$

Imre Vörös's conclusion is that the legislator in this way may remove from constitutional scrutiny any law regulating fundamental rights. Due to this irresolvable contradic-

18 Ibidem 35.

19 I. Vörös, Vázlat az alapvetö jogok természetéröl az Alaptörvény negyedik és ötödik módositása után, "Fundamentum" 2013, vol. 3, pp. 61-64.

20 The Fourth Amendment to the Fundamental Law includes a number of other examples to this phenomenon beyond the hate speech regulations. For instance, the new paragraphs (2) and (3) added to Article VII as a result of the amendment make the fundamental right conditional in a way that is likely to be incompatible with the restriction standard of Article I of the Fundamental Law. Similarly, the new paragraph (3) of Article IX concerning political advertisements during elections presumably restricts the same right in violation of the general restriction standard; the above fundamental right therefore will not apply to election law and a constitutionality review is impossible. 
tion in the logic of law, the affected fundamental rights will not be able to serve their legal protection function in accordance with the requirement of legal certainty.

The content of Article IX (5) of the Fundamental Law is uncertain due to other provisions of the Fundamental Law, the general interpretation framework of the basic right and the obligations under international law based on Article $Q$ of the Fundamental Law. As a result, Article IX (5) alone will not explain the constitutional content of Section 2:54 of the Civil Code. It is beyond doubt that Section 2:54 (4) and (5) need to be assessed within a new constitutionality framework and the existing practice of courts and the Constitutional Court must be re-evaluated. However, there is no clean slate, and the above prove that the freedom of expression and, naturally, the right to human dignity both have a core, an essential content and restriction standard that will not be changed in a democratic society, not even by the adopter of the constitution, the legislator or the courts. $^{21}$

\section{The Civil Law Regulation}

After a number of fruitless attempts at regulating hate speech (offensive speech) ${ }^{22}$ had been blocked by the Constitutional Court in recent years in Hungary, the Parliament added a new anti-hate speech rule to the new Civil Code, which took effect on 15 March 2014. Section 2:54(5) of the new Civil Code allows private individuals to enforce a claim against offenders in cases of hate speech:

In the event of a violation of rights committed before the wider public and seriously offensive to the Hungarian nation or to some national, ethnic, racial or religious community or unreasonably insulting for these groups in its manner of expression, any member of these groups is entitled to enforce his or her personality right in relation to him or her belonging to such groups, being an essential trait of his or her personality. The right to make a claim will be precluded after a period of thirty days from the injury. With the exception of surrendering the material advantage

21 Section 2.3 of the statement of reasons of Decision 143/2010 refers to this.

22 The term "hate speech" is typically used for expressions threatening the foundations of a democratic political system and is reminiscent primarily of totalitarian ideologies. More specifically, hate speech propagates racial, ethnic or national supremacy and incites hatred for this purpose. A. Sajó, A szólásszabadság kézikönyve, Budapest 2005, p. 133. In this paper, with regard to the above, I use the term "hate speech" as a synonym for collective defamation, a conduct offensive to individuals through the attack towards entire communities. This meaning is reflected in the examined piece of legislation as well. 
achieved through the violation, any member of the community may enforce any sanction available with regard to violations of personality rights. ${ }^{23}$

In order to eliminate any concerns related to the constitutionality of the new rule, the governing parties, relying on their two-thirds majority in Parliament, adopted the Fourth Amendment to the Fundamental Law shortly after passing the new Civil Code; the amended Fundamental Law now includes a provision ${ }^{24}$ that makes it possible to sanction hate speech.

Around the turn of the millennium, it became clear that the legal disputes related to hate speech were not resolved successfully by voluntary means, and courts were reluctant to extend, through a simple act of legal interpretation, the existing protection of personality rights to cases when the violation of the individual's rights could have been assessed with regard to conduct offending the community. As a result, such conflicts of interest or disputes were settled neither voluntarily and amicably, nor through the state's coercive measures. In 2007, Parliament specifically wanted to codify a rule in civil law allowing a member of a community suffering a serious public grievance due to his or her member status to take legal action. The rule would have authorised civil law courts to award damages to be paid by the person expressing hatred. The provision of law amending the personality rights chapter of the Civil Code was annulled by the Constitutional Court. ${ }^{25}$

A common criticism of anti-hate speech regulations in civil law is that they change the civil law system of personality rights, due to primarily public law considerations. However, due to the regulatory nature of personality rights, we believe that the new regulation in Section 2:54 of the Civil Code should rather be seen as a result of organic development and not as a forced restriction on private autonomy. This is because creating a personality right is simply allowing the law to define what conduct breaches the freedom of others and what does not breach it in the relevant field of regulation. A personality right therefore is a restriction but it is also a guarantee that autonomy will continue to exist within the new framework. ${ }^{26}$

23 'Personality right' is a continental - especially German - concept. Under common law jurisdiction, this concept does not exist; instead, there is tort for libel etc. However, for the sake of the description of the Hungarian concept I use the expression 'personality right' with the limitations of this translation.

24 Article IX. (5) of the Fundamental Law states that "The right to freedom of speech may not be exercised with the aim of violating the dignity of the Hungarian nation or of any national, ethnic, racial or religious community. Members of such communities shall be entitled to enforce their claims in court against the expression of an opinion which violates the community, invoking the violation of their human dignity, as provided for by an Act".

25 I will discuss the reasons behind this decision below.

26 L. Sólyom, A személyiségi jogok elmélete, Budapest 1983, p. 274. 


\section{Is it Possible to Regulate Hate Speech by Civil Law?}

According to an approach rooted in Roman law, pecuniary damage is handled more individually than iniuria (illegal behaviour towards another person, a personal insult); with regard to the latter, even the question of whether the grievance had arisen at all depended on public perception. ${ }^{27}$ As iniuria grew separate from physical assaults, it started to rely not on an abstract idea of personality and not on the status of a Roman citizen but on the current social customs. ${ }^{28}$ The pattern of conduct was defined by public morals, and the illegal conduct, in addition to insulting the targeted person, also qualified as a violation of public order. It was the praetor who interpreted the content of morals, and he had to assess even if the situation was clear whether the conduct had violated morality. ${ }^{29}$ It was very uncertain whether a claim purely based on private interest would be upheld, as publicity and public order particularly substantiated a claim. ${ }^{30}$ However, the iniuria as a private delict, originally concurrent with criminal law charges, was never used to protect public morals in general, as the iniuria was always targeted against a specific person.

In liberalism, the state wanted to provide economic guarantees to the personality to counterbalance the dominant position of the market. With the state regulating the economy and developing social functions, the protection of personality gained direct political interpretation. ${ }^{31}$ In the 20th century, according to Szladits, a most famous Hungarian legal scholar, 'the socialisation of the private law order', ${ }^{32}$ i.e. giving strong consideration to the community's interests, was the most dominant in the Nazi approach to private law. Advocates of the new approach believed that community considerations are the foundation of all civil law rules. Such a combination of private law and elements of public law was definitely a product of the crisis at the time, that is, a natural consequence of social and economic transformation, and an increased level of government intervention was an inherent part of these developments. ${ }^{33}$

Private law, however, has always been an individualistic system of laws (except for in crisis periods) because its objective is to strike a fair balance between conflicting private interests. The ideal of a bourgeois society, in which the weak must be protected from the stronger groups, had a noticeable impact in each field of law in the course of historical development. With the emergence of modern constitutions, it was a typical 19 th century phenomenon that administrative and criminal law elements were removed

27 Ibidem, p. 148.

28 Ibidem, p. 149.

29 Ibidem, p. 151.

30 Ibidem, p. 149.

31 Ibidem, p. 314.

32 Cit per: K. Szladits, A magyar magánjog. Általános rész. Személyi jog. Elsó rész, Budapest 1941, p. 36. L. Staud, A magánjog ethizálása - vagy pedig a természet jog felé? "Jogállam” 1926, vol. 1-2, pp. 38-42.

33 K. Szladits, A magyar magánjog..., p. 37. 
from private law with the reasoning that such elements belong in the constitution. ${ }^{34}$ The rules governing equal liberty, later equal human dignity, the prohibition of discrimination and then the requirement of equal treatment went through duplication at the levels of private law and constitutional law. However, the distribution of personality protection rules between branches of the law does not mean that the objectives and principles of these rules would be different.

The general opinion is that personality rights have three 'statutory roots': internationally recognised human rights conventions, the Hungarian Constitution and the basic principles of the Civil Code. According to Szladits, the basic difference between the rights in the Constitution and the personality rights in the Civil Code is that while the human rights specified in the Constitution must influence the entire state organisation and the conduct of individuals, the personality rights in the Civil Code are only granted to persons/entities of civil law and bodies applying civil law. ${ }^{35}$ It is a result of the triple statutory basis of the interpretation of personality rights that the Civil Code's provisions analysed in this paper must be applied and interpreted in accordance with the foundations. These foundations can be identified not just in public law but also in the historical development of private law. For these reasons, it is not unacceptable for civil law to incorporate antihate speech rules.

\section{The Content Neutrality Principle: the Interpretation of 'Seriously Offensive' and 'Unreasonably Insulting' Conduct}

As opposed to the anti-hate speech regulations common in foreign legal systems that sanction specific content regardless of the consequences, ${ }^{36}$ the rule of the Hungarian Civil Code is content-neutral to some extent, because it requires the conduct to be of such gravity that is capable of achieving a seriously offensive or unreasonably insulting result. The violation of the personality right, therefore, does not simply consist of the expression and perception of the hateful content: the speech must have a seriously offensive and unreasonably insulting effect.

When Section 2:54 of the Civil Code is applied by the courts, it will be a key test when a 'violation of rights ${ }^{37}$ will qualify as a violation of rights committed before the wider public and is seriously offensive or unreasonably insulting for these groups in its manner of expression, whether this criterion will apply to the community or individuals belonging to the community, and to what extent this test will be objective or whether it will be indi-

34 Ibidem, pp. 40-44.

35 G. Jobbágyi, Személyi jog, Miskolc 1996, p. 51.

36 For instance, the statutory definitions of Holocaust denial in many European countries.

37 Beyond the fact that the term 'violation of rights' in this context does not make much sense grammatically, it is also an unsuitable term here because, as discussed below, neither constitutional law nor civil law grants rights to communities. 
vidualised based on the person seeking legal remedy. When this is assessed by the courts, they will surely take the evaluation criteria developed for defamation cases in judicial practice into account and, in addition to identifying general guidelines of interpretation, the constitutional interpretation (as necessary also with regard to the general principles of the Civil Code) in specific cases will have to be found in such a manner that the court does not restrict the freedom of expression unnecessarily and disproportionately. ${ }^{38}$

According to Section 2:54 of the new Civil Code, a member of the relevant community may make a personality right claim in the event of a violation of their rights committed before the wider public and seriously offensive to or unreasonably insulting for the community in its manner of expression. It follows from the content in the previous sections that, in a personality rights context, an insult to the community rather means that the hateful conduct shown towards the community actually insults or hurts an individual belonging to the given community. A violation of rights may therefore only qualify as a violation of rights under civil law if it is indeed a violation of the rights of an individual belonging to the community in question.

On the basis of the grammatical interpretation of the phrase 'a violation of rights committed before the wider public and seriously offensive or unreasonably insulting for the community in its manner of expression', we may conclude that a less vulnerable community (such as the Hungarian nation) is less sensitive to the same insult as a vulnerable and disadvantaged minority.

The part of the rule in Section 2:54 of the Civil Code analysed in this section therefore moves back closer to the content neutrality principle, thus allowing the courts to impose sanctions for hate speech in particularly serious cases, taking the standard of necessity and proportionality into account.

\section{The Act on Equal Treatment in Administrative Law and Hate Speech}

In Hungary, Act CXXV of 2003 on Equal Treatment and the Promotion of Equal Opportunities is also a key regulatory reference. Compliance with the principle of equal treatment is traditionally ensured within the scope of administrative law, at least in European legal systems and in the language and institutional logic of EU directives. Its essential feature is that, unlike the logics of criminal and civil law, it imposes compulsory behaviour on the actors of both the public and the private sectors, therefore it may be appropriate to penalize phenomena and practices which cannot be effectively handled by other fields of law.

38 F. Gárdos-Orosz, Alkotmányos polgári jog? Az alapvetó jogok alkalmazása a magánjogi jogvitákban, Budapest 2011, pp. 118-146. 
In addition to that, in legal practice there are attempts to interpret the various legal regulations on discrimination in a broader sense, mainly due to strategic litigation and the innovative, law-developing efforts of human rights organisations. An example of that is the trial tactics that aim to reduce racist public speech claiming that racist statements made by politicians, state and local government officials constitute harassment, and imposing administrative sanctions for violating the principle of equal treatment. Two cases of this kind are known from the practice of the Supreme Court (Legfelsőbb Bíróság), in which the courts, in principle, did not rule out such interpretation of harassment, although the cases have not been successfully closed till the completion of this paper.

The first case was based on certain statements considered racists made by the Mayor of Edelény, Oszkár Molnár, at meeting of the municipal council on 24 June 2009, aired by the local television, which caused indignation in the local Roma community. The Equal Treatment Authority stated that the mayor's statements violated the right to human dignity and in effect, they were able to create an intimidating, hostile, humiliating, degrading or offensive environment, that is to say, the mayor violated the principle of equal treatment and committed harassment. The Metropolitan Court (Fővárosi Bíróság) in its final judgement of 22 March 2010, dismissed the mayor's claim that challenged the legality of the administrative decision. Later, the mayor applied for a review of the final judgement on grounds that, inter alia, his statements were not subject to the Act on Equal Treatment, as the complainants in the case were not residents of Edelény, and he could not be considered a mayor in relation to them, so there was no legal relationship between them. In its decision of 16 March 2011 adopted without a hearing, the Supreme Court found the mayor's request for review to be justified and repealed the decision of the Equal Treatment Authority. In the reasoning, the only issue that the Supreme Court examined was whether the mayor's statement fell within the personal scope of the act, thus the Supreme Court did not rule out the interpretation of law that considers racial hate speech widely spread in public discourse as harassment, which can be sanctioned for violating the principle of equal treatment.

Before that case, the Commissioner for Minorities had also attempted to establish a link between hate speech and the principle of equal treatment by submitting a legislative proposal, but it failed at an early stage. Nevertheless, the Equal Treatment Authority pointed out that, even under existing law, there is a possible legal interpretation that provides opportunity for the administrative intervention, taking into account Decision no. 96/2008. (VII. 3.) of the Constitutional Court.

Judgement of 18 October 2011 of the Supreme Court, which reviewed the decision of the Equal Treatment Authority concerning the mayor of Kiskunlacháza was, in many aspects, similar to the Edelény case. Here as well, the Equal Treatment Authority considered a speech against the Roma as harassment. The Metropolitan Court, in the judicial review of the administrative decision, similarly to the Edelény case, accepted the 
mayor's view that the statement was not subject to the act, repealed the administrative decision of the authority and ordered a new procedure on grounds that the mayor's speech remained within the scope of the freedom of expression, as it was not delivered at a city council meeting but at a public forum, where, although he attended as mayor, he was not acting in his official capacity. In its request for review, the authority claimed that the court committed an error by stating that the mayor was not acting in his official capacity. The Supreme Court found the request for review to a lesser extent justified, but mainly unjustified and ordered a new procedure.

These two cases confirm the notion that, in terms of the protection of human dignity and the restriction of hate speech, anti-discrimination law is an exceptionally effective and flexible area of law, which is easily adaptable to new circumstances, because the concept of anti-discrimination is dynamically changing and its content is constantly expanding, and harassment provides a basis for a number of specific acts, for example fight against hate speech, as a form of discrimination.

\section{The Restrictions of Hate Speech in Media Regulation}

\section{The Regulatory Framework of the Administrative and Judicial Practice on Hate Speech in the Media}

The regulation of offensive speech in the Hungarian law has started with the Act 1 of 1996 on the radio and television regulation (Rttv.), that applied to the electronic media. The most important provision was the following in article 3 . § (2) and (3).

3. $§(2)$ The broadcaster must observe and honour the constitutional order of the Republic of Hungary, his activity may not offend human rights and must not be instrumental to the rise of hatred against individuals, sexes, populations, nations, or ethnic, linguistic or other minorities or against churches or groups of a religious persuasion."

(3) Broadcasting must not be intended to offend or prejudice, explicitly or indirectly, any minority or majority or to present or prejudice minorities or majorities based on racial criteria.

The introduction of this regulation made it possible that the media authority (Országos Rádió és Televízió Testület, ORTT) could act against such media content that incited hatred or was otherwise exclusive

In the case of media law measures, unlike criminal law measures, it is not the communicating individual (the journalist or the editor) who is held responsible but the media service provider. Applying an extensive range of sanctions from simple warning to 
a fine or, in case of the most serious violations, withdrawal of the right to provide media services, the media authority sanctions the media service provider. The violation is adjudicated by the media authority in an administrative procedure, and the administrative decision can be subject to judicial review.

The new regime of media regulation enacted in 2010 changed the former regulation, which had been in force for 14 years. As a significant change, the Act on the Freedom of the Press and the Fundamental Rules of Media Content specified restrictions on content not only for radio and television broadcasters but for all media service providers. The adopted law attempted to extend the previous constraints, in a substantively unchanged form, to the printed and online media. But the act was amended shortly after its entry into force, due to objections raised by the European Commission, for the reason that the regulation imposed disproportionate constraints on the freedom of the press. The amendments also affected the provisions against hate speech. The existing provisions prohibit hate speech in the media as a general rule, not only in the electronic, but also in the printed and online press:

Section 17 (1) The media content may not incite hatred against any nation, community, national, ethnic, linguistic or other minority or any majority as well as any church or religious group.

(2) The media content may not exclude any nation, community, national, ethnic, linguistic and other minority or any majority as well as any church or religious group.

Enforcement of the regulation remains the role of the media authority, which, just as before, adjudicates the media law violation and applies media law sanctions in an administrative procedure.

\section{Criminal Law Standard - Media Law Standard - Which One is Correct?}

After adoption of the media law provisions against hate speech, legal practice has come up with a crucial issue: how do the media law provisions relate to the existing criminal law restrictions? Do they describe the same conduct, are the media law standard and the criminal law standard identical, or do media regulations impose a stricter prohibition, and provide a different intervention threshold to the media authority?

There are two cases, in which the Constitutional Court reviewed the constitutionality of the media law restriction on hate speech and, in both cases, considered the new media law provisions as necessary and proportionate restrictions on the freedom of the press. In a decision adopted in 2007, which contained an assessment of the previous regulation, the Constitutional Court measured the media law restraints on hate speech and the media law prohibition of inciting hatred to the criminal law restrictions, that is to say, the Constitutional Court did not apply a new media-specific argument to justify the restric- 
tions under Section 3(2) of the Act. ${ }^{39}$ It found that the criminal law and media law provisions of incitement to hatred describe the same conduct and stated in its reasoning that:

Criminal law is the last resort in the legal liability system. This means that, if for any socially harmful conduct, in our case, incitement to hatred, criminal responsibility is neither exaggerated, nor unconstitutional, then no restrictions on the same conduct under any other branch of law can be exaggerated or unconstitutional.

However, the Constitutional Court considered that the restriction referred to in Section 3(3) of the Act gives a constitutionally justifiable opportunity for broader intervention than the criminal law restriction, and compared the media law regulation to the crime of 'using abusing language', which had been removed from criminal law.

\begin{abstract}
According to the practice of the Constitutional Court, although, in the case of 'using abusing language' the application of the most stringent - criminal law-measures of liability is not justified, but expressing opinion in such way (as a value judgement) can also be restricted in order to protect the honour and dignity of individuals and communities. (...) The regulation aims to prevent radio and television from being an 'amplifier' of offensive, racially-motivated, and exclusionary or discriminative statements of those pursuing hatred.
\end{abstract}

Thus, while in 1992 the Constitutional Court found the criminal-law restriction of 'using abusing language' like expressions unconstitutional, the media-law restriction was considered to be "compatible with the value system of the Constitution, and its strengthening, and necessary to protect the rights of others, and the dignity of communities". That is to say, the Constitutional Court set the media law standard for intervention lower than the criminal law standard. But at the same time, it pointed out that the possibility for administrative intervention is not available based on the primary communication:

The conduct of the broadcaster in this regard cannot be judged on the sole basis of which opinions are allowed to be presented. It is necessary to examine whether, in the light of all the circumstances of the case, it seems plausible that the given programme itself had an intention to infringe the rights of others (e.g. the preparation of the programme, the way the opinion was presented, or whether the reporter distanced himself/herself from the opinion voiced).

39 B Török, A gyúlöletbeszéd tilalmának médiajogi mércéje, in: A gyúlöletbeszéd korlátozása Magyarországon, ed. A. Koltay, Budapest 2013. 
In this regard, the Constitutional Court based its reasoning on the case-law of the European Court of Human Rights, and set out requirements for the implementation of the given rules on that basis.

Thus, in this decision, the Constitutional Court set media law standards lower than the threshold of criminal law intervention, and, as the practice of the media authority will show, the ORTT (the former Hungarian Media Authority) developed a system of media law intervention, which is more extensive than that of criminal law.

The provisions on incitement to hatred in the new media regulation coming into force force as of 2011 have become subject to a review of constitutionality after a relatively short period of time, at the end of 2011. In its Decision no. 165/2011. AB on the constitutional review of several elements of the new regulation, the Constitutional Court analysed the new media regulation on hate speech rather briefly, and it did not provide clear guidance on how the criminal law standard relates to the media law standard. It stated that:

In Decision no. 1006/B/2001 AB, the Authority equated incitement to the hatred under Section 3(2) of the Act (Radio and Television Act) to the conduct element having the same content in the crime incitement against a community, since the latter is also penalised by criminal law, and accepted it as a constitutional basis for restricting the freedom of the press.

In addition, "since the Constitutional Court, in its case-law has already considered hate crimes committed by the press as a necessary restriction on the print media as well, in this ruling, the court only upheld its former view". However, the Constitutional Court did not separately review Section 17(2) of the Act, despite the fact that it is contains an independent prohibition of exclusion. ${ }^{40}$ The absence of constitutional review on this point makes the media law standard difficult to define, also because the conduct described in the new regulation bears similarity to the provision which the Constitutional Court had previously declared to be a lower threshold of intervention than that of criminal law.

In 2007, the Constitutional Court cited the media effect as an additional argument for regulation. It advocated the constitutionality of a lower intervention threshold arguing that electronic media - given "the opinion-shaping effect of radio and television broadcasting and the convincing power of moving images, voices, and live reports" - should be prevented from becoming an "amplifier" of hate speech. However, with the extension of scope, the new media law effective as of 2011 does not only apply to electronic media, but

40 A. Koltay, G. Polyák, Az Alkotmánybiróság határozata a médiaszabályozás egyes kérdéseiról, "Jogesetek Magyarázata” 2012, vol. 1., pp. 11-48. 
to all media content services, including the print media. The failure to constitutionally evaluate this change can be considered a serious deficiency. ${ }^{41}$

The 2011 decision of the Constitutional Court, as compared to the previous one, established a more obvious link between the standards of criminal law and media law intervention, while, on the other hand, it leaves a number of questions unanswered, which leads to an uncertainty concerning the constitutional assessment of the new media law intervention.

\section{The Practice of the Media Authority Between 1996 and 2010}

\section{The Development of an Independent Media Law Standard}

The practice of the media authority has always been based on the determination of an independent media law standard that is different from that of criminal law. Pursuant to the previous media law that was in force until 2010, the media authority regularly applied sanctions against broadcasters for hate speech, and in the event of judicial review, the court hardly ever disapproved the decision of the authority. ${ }^{42}$ In an emblematic example of early case-law, the criminal proceeding ended without conviction, but the media authority imposed a media law sanction for hate speech. The procedure was based on a radio commentary, in which the author made openly anti-Semitic statements and called for exclusion of the Jews. Criminal proceedings were initiated against the author and the editor-in-chief for incitement against a community, but in the final judgement, following the first-instance conviction, the accused persons were acquitted by the court. According to the court, a presumed risk of infringement is not enough to establish criminal liability, as the degree and the explicitness of threat, and the degree of potential violence must be evaluated. It argued that the writing did not call for violence, and from the provocation: 'exclude them! or if you don't, they will do it to you' it did not follow or could not be deducted that the intention of the accused was to encourage his readers/listeners to commit violent acts. In contrast to the judgement, the media authority found that the radio programme had violated Section 3(2) and (3) of the Act and it imposed a relatively high fine of 1 million HUF on the radio provider. The authority argued that the programme conveyed extremist ideology, the broadcast expressions directly targeted Hungarian Jews and were capable of inciting hatred.

The media law standard set by the ORTT has been approved by case-law. In the judicial review of the decisions passed by the authority, the court stated that incitement against a community regulated in Section 269 of the Criminal Code (Btk.) cannot be confused with 'incitement to hatred' under Section 3(2) of the Act (Rttv.). In a case in

41 Ibidem.

42 A. Török, A gyúlöletbeszéd..., p. 177. 
which the authority found that a public service radio programme incited hatred, the Supreme Court finally stated that:

There is no legal basis for the applicant's argument that Section 3(2) of the Act (Rttv.) could only be violated by a conduct capable of rebounding outrageous and hostile emotions. Neither the wording of the given provision, nor the interpretation of other provisions of the Act supports this kind of exaggerating, intensifying interpretation of the law.

The 2007 decision of the Constitutional Court on the review of the constitutionality of anti-hate speech media regulation did not substantively change the practice of the media authority, although since the judgement, the decisions of the authority have contained more elaborate theoretical arguments regarding the media law standard. The reason for this is that the Constitutional Court, as noted above, stated in this judgement that the prohibition of incitement to hatred under Section 3(2) of the Media Act was equivalent to the crime of incitement against a community. However, based on its analysis of the Supreme Court and Constitutional Court practice, the media authority maintained its position that media law sanction can be imposed even if the conduct examined does not constitute a crime of incitement against a community. A part of the argument is that, in the Constitutional Court practice, the critera for the applicability of sanctions that are milder than criminal sanctions, like pecuniary penalty, "may differ from the strict requirement of restriction to a fundamental right that limits the applicability of criminal law means" which justifies a more extensive application of the media law sanction. Another part of the argument is that, the subject of the administrative procedure is different, since media law imposes restrictions on the broadcaster.

An additional argument, which had been mentioned before in the decision of the Constitutional Court, is related to the media effect. The aim of imposing media law sanctions is to prevent the media from becoming an amplifier of hate speech. The decisions establishing infringement also contain the above-mentioned argument applied by the Supreme Court' that the media law violation cannot only be observed in case of 'extreme, flagrant behaviour that causes hostile emotions'. On the basis of all this, the media authority came to the conclusion that "the constitutional framework for the assessment of the same conduct may be different under media law and under criminal law". ${ }^{43}$

43 Decision of the ORTT 1949/2008 


\section{Case-law: Context, Intent, Content, Effect}

Since the milestone decision of the Constitutional Court from 2007, the media authority has established violation of the provisions of the Act on grounds of incitement to hatred on several occasions. The media authority typically applied sanctions in case of incitement to hatred against the Roma community, anti-Semitic expressions, and incitement to hatred against other minority groups. Most of the time, news and information programmes were sanctioned, and the authority responded to hate speech expressed in specific programmes. For example, the authority described a television programme in which the presenter himself formulated a biased view about the Roma as incitement to hatred.

The Roma population living in the countryside was shown as an aggressive, fertile group of people, leading a drinking and criminal lifestyle. It claimed that the minority's only legitimate source of income was from different allowances, which, according to the presenter, could ensure them a better standard of living than certain employed members of the majority have. ${ }^{44}$

The decision emphasised that the programme could directly reinforce negative stereotypes and prejudices against the Roma. In the judicial review of the decision, the court accepted the decision in approval of the reasoning presented by the authority and emphasised that also the method of editing applied, with the presenter highlighting the crimes and abuses committed by the Roma against the Hungarians, and attributing all the unlawful acts to the Roma, was capable of reinforcing the opposition between the minority and the majority.

The authority also cited Section 3(2) in the case of programmes which displayed expressions of hate speech sent by the audience via text messages ${ }^{45}$ The media authority consistently applied media law sanctions on such programmes, since, in its view, the broadcaster should have filtered out messages that incited to violence and hatred. The authority considered that the failure to filter them out meant that from the series of text messages shown, it could be inferred that the broadcaster's intention was to incite hatred, which justifies the applicability of the media law sanction.

There are special cases in the case-law of the authority, in which the authority reviewed not news and information programmes, but rather programmes categorised as entertainment. The first decision ${ }^{46}$ of that kind was adopted in 2003, concerning a parody programme broadcast by TV2, the second largest commercial television in the country. The fundamental question examined regarding the programme was, considering the

44 Decision of the ORTT 1949/2008.

45 Decision of the ORTT 1996/2008.

46 Decision of the ORTT 367/2003. 
special features of the entertaining genre, where the limit of editorial freedom is, what kind of an expression can clearly be considered as harmful to one's interests, and inciting hatred. The programme titled Bazi nagy roma lagzi (Big Fat Roma Wedding) presented the Roma minority in a parodistic and stereotypical way, introducing the Roma community by presenting exclusively deviant, antisocial forms of behaviour. According to the decision of the authority, the scenes displayed in the programme, based on clearly negative stereotypes concerning the Roma minority, which are already present in society, were, without doubt, capable of strengthening prejudices against the Roma minority.

The authority found that the fact that a particular programme conveyed its message to the audience in a fictional, humorous way, could, on the one hand, exert increased impact on the audience by making people laugh, while, on the other hand, it distracted viewers from the potentially offensive and exclusionary nature of the content, that is to say, the specific genre, in this case, even enhanced the gravity of the infringement.

The responsibility of the broadcasters in connection with the editing practice of programmes belonging to the so-called talk-show genre was assessed by the authority in a similar way. In a procedure concerning afternoon talk-show programmes on the two major nationwide commercial televisions (RTL Klub, TV2), the authority established the infringement based on the review of broadcasts over a period of several months. The decisions of the authority made it clear that the programmes did not aim to present the Roma minority, still, the editing practices of the programmes conveyed an indirect message that was suitable for depicting the Roma minority in a racially offensive manner, which means that, the broadcasters violated Section 3(3) of the Act by airing these programmes. ${ }^{47}$

According to the reasoning of the decisions, in these programmes, the Roma minority was clearly over-represented as compared to its actual representation in society, and the themes portrayed by the Roma participants (promiscuity, domestic violence, drug abuse, alcoholism, child abuse, crime), together with the value-deficient, uncultured behaviour, vulgar speech, untidy, messy look demonstrated in the studio were suitable for reinforcing the stereotypical, prejudicial thinking that exists in the majority population about the Roma.

In the procedure conducted, the authority based its decision on investigations applying quantitative and qualitative methods. The investigation, based on a detailed set of criteria, analysed the content of the programmes of both television programmes, aired over several months, and focus group surveys. The latter were also carried out to assess and analyse the impact of the programmes.

In the course of the proceedings, the ORTT took into account the case-law of Strasbourg, which was also mentioned in the Constitutional Court decision cited before: it 47 Decisions of the ORTT 2052/2009; 2053/2009; 291/2010; 292/2010. 
did not examine the responsibility of the televisions alone on the basis of the opinions expressed, but evaluated the editorial practice of the programme, the messages it conveyed, and its effects.

Concerning the case-law of the ORTT, it can be stated in summary that the authority has gradually established the framework for the interpretation of media law constraints on hate speech, and it consistently set the media law standard below the threshold of criminal intervention, and used the set of criteria developed by the European Court of Human Rights to justify the limitation of free speech.

In the last few years, beyond reacting to individual statements, the ORTT also showed efforts of media control to apply sanctions against hateful media contents that can be understood as being general phenomena in the media contents on offer.

\section{Practice of the media authority between 2011 and 2017 Restrained intervention}

In connection with the new media legislation that entered into force in 2011, many international organisations, including various institutions of the European Union have expressed sharp criticism in protection of the freedom of the press, for several reasons, including the extension of the scope of regulation to the print media, the widely formulated restrictions on content, and the lack of guarantees to ensure the independence of the media supervisory authority. Partly in response to the Commission's objections, partly by due to the Constitutional Court decision, the regulations were significantly amended within the same year. The amendments affected the media regulation on hate speech to a marginal extent only, and later the Constitutional Court - as it has been mentioned before - found the media law restrictions on inciting hatred constitutionally justifiable.

The practice of the new media authority can be characterised by restraint; in the field of content control, it intervenes in a much narrower scope than the former authority had, even though the rules would provide opportunity for a more extensive control. This general statement is also valid for measures taken against hateful and exclusionary contents. While in the last few years of the former authority, several decisions established infringements each year, the new media authority sanctioned hate speech only in one or two cases each year. While at the same time, it is generally believed that hate speech in the world of media has not decreased but much rather increased, especially due to the fact that the refugee issue has appeared as another leading topic.

\section{An Independent Media Law Standard}

The practice of the media authority has not changed concerning anti-hate speech media law and criminal law standards. In line with the previous practices, the authority sets a lower threshold for media law intervention. In response to the new provisions of media 
law and the ruling of the Constitutional Court explained before in detail, it interprets the content of the media law prohibition as follows:

The Media Council finds that the prohibition of "incitement to hatred" under media law (the new Media Act, Smtv.) and "incitement to hatred" under criminal law (Criminal Code, Btk.) are essentially the same, that is to say, the reviewed content is adjudicated on the basis of the same standards. However, taking into account that the legal dogmatics and liability systems of criminal law and administrative law are different, the conditions for establishing an infringement (crime) are also different. Pursuant to Section 17(1) of the Media Act, alone the publication of media content that is capable of inciting hatred constitutes an infringement. It is therefore not necessary to arouse the feeling of hatred in the audience and, consequently, it is not required either that the attacked community is actually hurt or threatened. ${ }^{48}$

The aforementioned argument appeared in a decision that reviewed an essay published in a printed newspaper and its online version, in which the authority imposed media law sanction on grounds of incitement to hatred and exclusion. Reflecting on a serious criminal offence, the author of this essay depicted a 'substantial part' of the Roma minority as a group of criminalised people inclined to commit crimes, rejecting social norms, routinely violating Hungarian laws, demonstrating inhuman forms of behaviour:

And the facts are these: a substantial part of the Roma is not capable of living together with others. They are not capable of living together with human beings. This part of the Roma consists of animals, and they behave like animals. And animals should not exist. Not at all. This is the issue we need to tackle, but immediately and in any way! ${ }^{49}$

According to the Media Council, the opinion expressed in the article was able to incite hatred against the Roma community, even though it did not target the whole community, but "only” a substantial part of it. 'Substantial part' means generalisation that affects the community as a whole. Moreover, the author suggested retaliation, violence, private justice as a solution, which is incompatible with a democratic legal system.

According to the Media Council, the message conveyed by the article reached the threshold of the violation of law, since, by carrying the possibility and the danger

48 Decision of the Media Council 802/2013.

49 Decision of the Media Council 802/2013. 
32 Adam Mickiewicz University Law Review

to foment emotions against the Roma minority, it was capable of inciting hatred against not only a substantial part of the Roma, but the whole community. ${ }^{50}$

By the way, the public prosecutor's office also conducted investigations because of the article, but in the end no criminal proceedings were initiated.

\section{Literature}

Gárdos-Orosz F., Alkotmányos polgári jog? Az alapvetó jogok alkalmazása a magánjogi jogritákban, Budapest 2011.

Gárdos-Orosz F., The Regulation of Offensive Speech in the Nerw Hungarian Civil Code, „ELTE Law Journal” 2015.

Gerards J., How to improve the necessity test of the European Court of Human Rights, "International Journal of Constitutional Law"2013, vol. 11.

Giliker P., Beckwith S., Tort, London 2000.

Halmai G., Criminal Law as Means Against Hate Speech? The Hungarian Legal Approach, "Journal of Constitutional Law in Eastern and Cetnral Europe"1997, vol. 4 / 1.

Halmai G, Scheppele K. L., eds. Amicus Brief for the Venice Commission on the Fourth Amendment to the Fundamental Law of Hungary, "Fundamentum" 2013, vol. 3.

Halmai G., Tóth A. Emberi jogok, Budapest 2003.

Jobbágyi G., Személyi jog, Miskolc 1996.

Koltay A., Polyák G., Az Alkotmánybiróság határozata a médiaszabályozás egyes kérdéseiról, "Jogesetek Magyarázata" 2012, vol.1.

A. Koltay, The Clear and Present Danger Doctrine in Hungarian Hate Speech Laws and the Jurisprudence of the European Court of Human Rights, in: Comparative Perspectives on Freedom of Expression, ed. A. Koltay, R. Weaver, M. D. Cole, S. Edland, „The Global Papers Series”, 2017, vol. II, Durham.

Michel R., Hate Speech and constitutional jurisprudence, a comparative analysis, in: The Content and Context of Hate Speech. Rethinking Regulation and Responses, ed. M. Herz, P. Molnár, Cambridge 2012.

Molnár, P., Towards Improved Policy and Hate Speech - the Clear and Present Danger Doctrine in Hungary, in: Extreme Speech and Democracy, ed. I. Hare, J. Weinstein, Oxford 2009.

Paul B. C., Censored: How European 'Hate Speech' Laws are Threatening Freedom of Speech, Vienna 2012.

Sajó A., A szólásszabadság kézikönyve. Budapest 2005.

50 Decision of the Media Council 802/2013. 
Sólyom L., A személyiségi jogok elmélete, Budapest 1983.

Staud L., A magánjog ethizálása - vagy pedig a természet jog felé?, "Jogállam"1926, vol.1-2. Szladits K., A magyar magánjog. Altalános rész. Személyi jog. Elsö rész, Budapest 1941.

Török B., A gyúlöletbeszéd tilalmának médiajogi mércéje, in: A gyúlöletbeszéd korlátozása Magyarországon, ed. Koltay A., Budapest 2013.

Vörös I., Vázlat az alapvetö jogok természetéröl az Alaptörvény negyedik és ötödik módositása után, "Fundamentum" 2013, vol. 3.

Decision of the ORTT 1949/2008.

Decision of the ORTT 1996/2008.

Decision of the ORTT 2052/2009.

Decision of the ORTT 2053/2009.

Decision of the ORTT 291/2010.

Decision of the ORTT 292/2010.

Decision of the ORTT 367/2003.

Decision of the Media Council 802/2013.

Constitutional Court Decision 143/2010

Constitutional Court Decision 1992

SUMMARY

\section{The Development of the Hate Speech Regulation in Hungary: From Criminal Law to Civil Law and Media Regulation}

In the Hungarian legal system, the anti-hate speech rules of media law provide an additional (administrative) proceeding for the media authority in parallel with proceedings under criminal law and civil law. The media authorities, over the past twenty years, have consistently set media law sanctions at a lower intervention threshold than criminal law did, and in many cases, they established media law violation in cases where criminal proceedings for incitement against a community were not initiated or ended in acquittal. The fundamental aim of media law regulation is to shape media content and the editing practices of media players with a view to ensure respect for human dignity, and to prevent media from becoming an 'amplifier' of hateful communications. In the first fourteen years of the Hungarian media regulation, the scope of interpretation concerning anti-hate speech media law restrictions developed gradually. The authority reacted not only to individual cases, and individual communications, but also carried out targeted investigations in cases that can be described as a phenomenon in the media coverage. Besides reviewing news and information programmes, it also acted against hateful contents of the entertainment programmes. The new media regulation, which entered into 
force in 2011, partially amended the content of the former anti-hate speech regulation: in addition to the provisions of "incitement to hatred", the former category of "offending or prejudiced content" was replaced by the prohibition of "exclusion". The practice of the media authority has not changed as regards the assessment of the media law standard, as the authority has continued to apply it differently from the criminal law standard, considering it as a lower intervention threshold. However, in comparison with pre-2010 practice, the authority initiated considerably fewer proceedings and its approach in terms of law enforcement became less characterised by adjudicating problems that can be described as phenomenon in the media coverage, no targeted proceedings of this kind were initiated. Its practice can be characterised by a couple of high profile cases with extreme sanctions, which attract great attention. These cases are important as they designate the boundaries of public communications, but in this way, media law measures are not really suitable for making any substantial changes to the characteristics of the media coverage.

Keywords: hate speech, freedom of speech, media law, discrimination, criminal law, constitutional law

Fruzsina Gárdos-Orosz, Centre for Social Sciences, Hungarian Academy of Sciences, 1453 Budapest, Hungary, e-mail: orosz.fruzsina@tk.mta.hu.

Krisztina Nagy, Faculty of Economics and Social Science, Budapest University of Technology and Economics, Budapest, Hungary, e-mail: krisztina.nagy@bme.hu. 